\title{
The Ottoman State Between Urban Space and Environment: Preserving the Drinking Water of Istanbul
}

\author{
Burcu Kurt*
}

\begin{abstract}
This study reveals the contribution of environmental and sanitarian factors to the shaping of the cities, particularly the Ottoman capital Istanbul. This paper, focusing on the second half of the $19^{\text {th }}$ century, discusses the man-made environmental destruction, the water shortage that emerged as a result of uncontrolled urbanization and the Ottoman state's evacuation process of the Belgrad, Kömürcü and Bahçecik villages due to the threat of disease. Thusly, this paper aims to shed light on the extent to which Ottoman urbanization was exposed to environmental influences.
\end{abstract}

Keywords: Istanbul, Ottoman Empire, Ottoman Environmental History, History of Urban Planning, Ottoman Cities

\section{Ekoloji ile Kentsel Mekan Arasında Osmanlı Devleti: İstanbul'un İçme Suyunu Muhafaza Etmek}

\section{$\ddot{O ̈}_{z}$}

Bu çalışma, başta Osmanlı payitahtı İstanbul olmak üzere, kentlerin şekillenmesine çevresel ve sshhi faktörlerin etkisini ortaya koymaktadır. 19. yüzyllın ikinci yarısına odaklanan makale, insan kaynaklı çevresel tahribatı, kontrolsüz kentleşme sonucu ortaya çıkan su sıkıntısını ve Osmanlı devletinin salgın tehdidi nedeniyle Belgrad, Kömürcü ve Bahçecik köylerini tahliye etme sürecini ele almaktadır. Bu noktadan hareketle çalışma, Osmanlı kentleşmesinin çevresel etkilere ne ölçüde maruz kaldığına ışık tutmayı amaçlamaktadır.

Anahtar Kelimeler: İstanbul, Osmanlı İmparatorluğu, Osmanlı çevre tarihi, Şehir planlaması tarihi, Osmanlı şehirleri

* Assoc. Prof., Istanbul Technical University, Departmen of Modern Turkish History, Istanbul/ TURKEY, burcukurt@itu.edu.tr ORCID: 0000-0002-5924-1779

DOI: 10.37879/belleten.2021.933

Application date of article: 10.06.2020 - Approval date of article: 02.08.2021

Belleten, Aralık 2021, Cilt: 85/Sayı: 304; 933-966 


\section{Introduction}

Environmental history studies first emerged as a new field in America in the 1960s-1970s, and made significant progress in parallel with various ecologic events including climate change, the disruption in the ecological balance and environmental disasters emerging on the world agenda. In the simplest definition, throughout history the dealings and interaction of people with their surroundings; the environmental history studies concerning the people's methods of using, managing and transforming the ecological environment, particularly with the effects of the Chernobyl catastrophe, over time became a topic of interest in America, and later in Europe ${ }^{1}$. Although there are studies since the early ages that can be related to the discipline we call environmental history today, it would not be misguiding to say that this field has only attracted the interest of researchers of Ottoman history in the last ten years ${ }^{2}$.

Undoubtedly, one of the most neglected fields in terms of Ottoman environmental studies is the relationship between the city and nature. For many years, the topic of whether the city was to be included in environmental history studies or not, or whether this only concerns rural areas has been a topic of debate among researchers both in America and Europe. As the direct connection between the city and nature became more recognized, studies on this topic became more popular in literature ${ }^{3}$. Even though the nature-human relationship in terms of the city's food and water supply were the topic of some studies regarding the Ottoman Empire ${ }^{4}$, Ottoman environmental history studies regarding the influence of nature on urbanization, spatial transformation and habitation policies are, so to speak, silent ${ }^{5}$. From this point of view, this study aims to reveal how nature, that was classified as a vehicle of control for the administration, redefined the city's planning policies by placing Istanbul, the capital of the Ottoman

1 Onur Inal, "Environmental History as an Emerging Field in Ottoman Studies: An Historiographical Overview", The fournal of Ottoman Studies, 38 (2011), pp. 1-4.

2 Inal, Ibid, pp. 5-23.

3 Inal, Ibid, pp. 13-15.

4 The studies in this field that first come to mind are: Mevlüt Camgöz, Ekmek, Buğday ve Şehir: 19. Yüzynl Osmanl İstanbul'unda İaşe Meselesi İstanbul, 2017; Arif Bilgin, Osmanl Saray Mutfă̆ (14531650) Istanbul, 2004; Suraiya Faroqhi, Towns and Townsmen of Ottoman Anatolia: Trade, Crafts and Food Production in an Urban Setting: 1520-1650 Cambridge, 1984; Tevfik Güran, "İstanbul'un İaşesinde Devletin Rolü”, İstanbul Üniversitesi Iktisat Fakültesi Mecmuası, XLIV (1986), pp. 245-75. Undoubtedly there are many more examples to add to the list.

5 For one of the rare exceptions see. John Ljungkvist, Stephan Barthel, Göran Finnveden, Sverker Sörlin, "The Urban Anthropocene: Lessons for Sustainability from the Environmental History of Constantionople", in Paul J.J. Sinclair, Gullög Nordquist, Frands Herschend, Christian Isendahl (ed.), The Urban Mind: Cultural and Environmental Dynamics, Uppsala, 2010, pp. 367-90. 
Empire under the scope, and presenting a humble contribution to the gap in this field. Therefore, the unplanned urbanization that emerged in the capital Istanbul in the nineteenth century due to population increase and consequently the water basins being opened as development areas, and the issue of the water shortage suffered as a result of all this will be revealed. This paper will be examining this ecological destruction caused by the lack of state inspection, transforming the city's habitation areas, and as a result the total destruction of two villages and partial destruction of one village that existed since the fifteenth century by the state.

Since Istanbul was conquered by Mehmed the Conqueror and transformed into an Islamic capital it has always been a place of attraction, and there was a steady population increase. Although certain urban historians suggest that Islamic cities emerged randomly and unplanned, Ottoman urbanization in the classical period materialized based on conventional organization under the control of the Sultan. In the Ottoman state, larger cities such as Istanbul had more than one city center, areas around religious and trade centers, each constructed as a part of a religious structure and financed by foundations also allowed for planned development based around these structures. But unlike these religious and trade centers, it is impossible to refer to places that can be classified as the settlement areas of these cities, as areas of planned urbanization ${ }^{6}$. In the 19th century, the development of transport technology that emerged with the industrial revolution, concern for public health, increase in life expectancy with the influence of medical discoveries and the migration movement to the Ottoman capital from various territories including Caucasus and the Balkans led to a significant increase in Istanbul's population. Since the second half of the $19^{\text {th }}$ century, both the physical growth of the capital due to the increasing population, and urbanization being considered a part of the modernization process forced the Ottoman state to take certain steps regarding urbanization. In this context, while the state sought the opinions of foreign urbanization experts on one hand, on the other the state also attempted to introduce laws that would serve urban planning and also regulate construction activities. The 1856 Aksaray and 1865 Hocapaşa fires were a turning point in urbanization development in Istanbul. After this, attempts were made until the end of the century to enable the reorganization and growth of Istanbul in the framework of various plans ${ }^{7}$. However, it would not be wrong in suggesting that

6 Halil İnalcık, "İstanbul: Bir İslam Şehri”, Íslam Tetkikleri Dergisi, 9 (1995), pp. 250-253.

7 For detailed information on the process of organizing the urban fabric of Istanbul, see. Zeynep Çelik, 19. Vüzynlda Osmanl Başkenti: Değişen İstanbul, Türkiye İş Bankası Kültür Yayınları, İstanbul 2019, pp. 63-108. 
a majority of these efforts applied mainly to the area that we can classify as the city center of Istanbul ${ }^{8}$. Therefore, despite all the efforts in this period, not all of the new settlement areas in Istanbul emerged as a part of controlled development, and certain green areas of the city were transformed into settlement areas without the approval or control of state officials. One of the areas that became uncontrolled settlement areas was the dams and their surroundings.

Since the second half of the nineteenth century, pollution was discovered in the waters of Bend-i Kebir (Great Dam), that was the most important water source for the capital Istanbul, and as a result of surveys it was determined that the cause of this pollution was the unplanned urbanization and development of illegal settlement areas around the dams (namely Belgrad, Kömürcü and Bahçeköy villages). In this study, focus will be placed on unplanned and uncontrolled urbanization that began to emerge in a way that became a threat to Istanbul's already inadequate water sources since the second half of the nineteenth century; the environmental and health issues this caused and how the state mechanism tried to solve this issue. In this way, attempts will be made to reveal the Ottoman administrative mentality of endeavoring to control nature in the second half of the nineteenth century in the Ottoman Empire by examining the debates concerning the relocation of Belgrad, Kömürcü and Bahçeköy villages that were polluting the Istanbul's water sources, and its view on the relationship between generating healthy individuals and maintaining the natural balance.

This study that focuses on the relationship between city and environment in the context of Istanbul -the capital of the Ottoman Empire-, at the same time aims to shed light on the history of the shortage of water, an environmental issue that still maintains its importance today. Taking into consideration that supplying water to the city of Istanbul maintains its vitality even today, in one sense this study also aims to contribute to the history of water shortage that Istanbul has faced for centuries.

8 Since the $19^{\text {th }}$ century, the population of Istanbul was concentrated mainly in the historical peninsular, Galata and Haliç. Üsküdar was the largest settlement area on the Anatolian side of the city. Üsküdar was followed by Kadıköy (Khalkedon). A significant expansion of the capital's physical borders began to emerge in the second half of the $19^{\text {th }}$ and first quarter of the $20^{\text {th }}$ centuries, and the borders of the city center expanded from Taksim to Şisli, along the coast from Tophane to Dolmabahçe, from Dolmabahçe to Teşvikiye then on towards Nişantaşı. Ibid, pp. 4851 .

Belleten, Aralık 2021, Cilt: 85/Sayı: 304; 933-966 


\section{Should the Villages be Relocated or not? Disputes Regarding the Fate of Villages in the Vicinity of Dams}

As fresh water sources are limited, this has posed a problem in supplying the water demand of Istanbul since the early times. Because there are no streams in the center of Istanbul, the city's water need was supplied from surface waters, water springs and wells outside the city $^{9}$. In the ancient Greek period, water needs were supplied from small sources and wells, whereas in the Roman period water supply systems were built from Thrace and the west of the city ${ }^{10}$. In the Roman era, the water sources in Halkalı and the other regions between the Istanbul city walls was collected and water was brought to the city via canals and aqueducts, and part of this water passed over the Valens (Bozdoğan) Aqueduct and was distributed to the city. However, during the sieges on Istanbul that began since the seventh century, these waterways were substantially destroyed, and in particular during the Latin invasion in the thirteenth century, the inner-city water distribution network was damaged to the extent that it was irreparable. For this reason, initially large open-air pools called çukurbostan were built to supply the city's water needs, and in later periods the city's water was supplied with huge cisterns constructed underground ${ }^{11}$. During the Ottoman period, supplying water to the capital Istanbul continued to be a major issue. Water shortages began to emerge in Istanbul, the capital of the empire that had become more congested and expanded to vaster borders particularly during the period of Suleyman the Magnificent. In an attempt of averting the water issue, Suleyman the Magnificent ordered the water to be supplied to fountains that were to be built in the city via the water canals around the Belgrad Forest, and accordingly the Kırkçeşme water facilities were constructed ${ }^{12}$.

While the water demand within the city walls (Suriçi) was supplied by the Kırkçeşme facilities, the water from Halkalı was planned to supply the higher

9 İlhami Yurdakul, Aziz Şehre Leziz Su, İstanbul 2010, p. 14.

10 Ahmet Tabakoğlu, Gülfettin Çelik, Suyu Arayan İstanbul: Vakıf Sular ve Kirkşeşme, İstanbul 2006, p. 147.

11 Osman Nuri Ergin, "Vesait-i İtfaiyyeden İstanbul Suları", in İsmail Kara, İlhami Yurdakul (ed.), 19. ve 20. Yüzynlda İstanbul Sulan, Vol. 1, İstanbul 2000, pp. 130-31; Galib Ata, "İstanbul Evkaf Suları", pp. 143-44. Kazım Çeçen, "Sinan’ın Yaptırdığı Su Tesisleri”, Mimarbaşı Koca Sinan, Yaşadiğı Çağ ve Eserleri, Vol. 1, Ankara 1988, p. 439.

12 Burcu Kurt, 'Payitaht'ın Suyunu Muhafaza Etmek: 1894 Depremi Sonrası Kırkçeşme Su Yolunun Tamiri', Kanuni Sultan Süleyman Dönemi ve Bursa, Bursa, 2019, p. 452. 
parts of the city and Beyoğlu ${ }^{13}$. Due to the increasing population, over a period of time the existing water system became inadequate, and during the reign of Mahmud I dams were built around Bahçeköy to supply water demands to this region $^{14}$. However, due to the ever increasing population, the dams could only meet water demands depending on whether there was sufficient rain or not. For this reason, there were major water shortages in Istanbul in periods when there was inadequate rain, and particularly during the summer months. Despite the growing population, it was only possible to supply the city's water needs with the construction of the dam and the addition of waterways until the end of the period of Mahmud $\mathrm{II}^{15}$.

At water supply facilities such as Kırıkçeşme and Halkalı which supplied the water demand of Istanbul, streams were swelled with the help of a minor connection and the required amount of water was supplied by means of canals. Grilles were placed at the mouths of the water inlets to prevent any floating substances from entering the canals ${ }^{16}$. Chimney shaped reservoirs were built every 20-40 meters along the entire water canals ${ }^{17}$. Water that was supplied from the source was carried to the circular sedimentation reservoir via covered canals, enabling the sinking and purification of solid substances. The volume of water that reached the city was measured with output reservoirs constructed at points where the water was to be supplied to different areas, and then distributed to the local water networks. The local water distribution network was generally supplied with clay or lead water pipes ${ }^{18}$. So while on one hand this source supplied the city's water demand, on the other attempts were also made to ensure the water reached the people in a clean and hygienic way.

The capital Istanbul that became a center of attraction as a result of the economic integration with Europe after Mahmud II, virtually faced a population explosion,

13 For detailed information about Kırkçeşme and Halkalı Water systems, see. Kazım Çeçen, İstanbul'un Osmanl Dönemi Suyollan, İstanbul Su ve Kanalizasyon İdaresi, İstanbul 1999, pp. 19195.

14 Yurdakul, Aziz Şehre Leziz Su, pp. 9-14.

15 In the second half of the nineteenth century, the water shortage reached such a extent that to solve the issue visitors from rural areas were banned from travelling to Istanbul. Ibid, pp. 14-15.

16 Kazım Çeçen, Istanbul'da Osmanl Devrindeki Su Tesisleri, İstanbul Teknik Üniversitesi, İstanbul 1984, pp. 8-9.

17 Yurdakul, Aziz Şehre Leziz Su, p. 8.

18 Çeçen, Istanbul'da Osmanl Devrindeki Su Tesisleri, pp. 9-12. 
especially in the second half of the century. Undoubtedly, the main cause of this was the influx of immigrants to the capital. The migration that began from Caucasus and the Balkans since 1862 reached a climax during, and also after the 1877-78 Russo-Turkish War ${ }^{19}$. On one hand, the increasing migration wave changed the city's urbanization dynamics, while on the other presented the issue of how to supply water, one of the main needs of the growing population. The water shortage began to be felt severely in Istanbul, especially in the Beyoğlu and Bosphorus regions during the period of Abdulaziz. Although various solutions were sought to supply water to Istanbul from 1851 to 1869 including constructing waterways, opening artesian wells, channeling water from the streams here before it reached the Terkos Lake, and pumping water to the Beyoğlu district from the Alibeyköy and Kağıthane streams using machinery, due to the high volume of water required and the plan being considered unpractical a major part of the project did not materialize ${ }^{20}$. One of the important solutions put forth to eliminate the growing water issue in the capital since the second half of the nineteenth century was the establishment of the Dersaadet (Istanbul) Water Company with concessions granted in 1879, and therefore the distribution of the clean water supply obtained from the Terkos Lake and Kizildere to Istanbul and the coastal villages in Beyoğlu, Galata and the Bosphorus ${ }^{21}$. Nevertheless, as the Terkos water would not be adequate to meet the water demands of all the residents of Istanbul and the fact that poorer people would not have the means to purchase water, made repairing the dams and waterways an issue of great urgency ${ }^{22}$.

Another aspect of the water issue in the capital was whether or not the already low volume of water was sufficiently clean. One of the major reasons for the people of Istanbul facing a water shortage without doubt was that maintenance could not be carried out on the waterways due to the economic crisis the empire suffered following the 1875 moratorium. One of the other reasons was the population growth in Istanbul in the nineteenth century and the city's water basins being opened for uncontrolled urbanization as a result of the sayfye (summer house)

19 Literally, the population of Istanbul in 1885 and after this consisted mainly of migrants. According to the 1885 census, almost $60 \%$ of the population was born outside Istanbul. Kemal H. Karpat, Osmanl Nüfusu (1830-1914), İstanbul 2003, pp. 141-44.

20 Saadi Nazım Nirven, İstanbul Sular İstanbul 1946, pp. 196-197; Yurdakul, Aziz Şehre Leziz Su, pp. 19-23.

21 Yurdakul, Aziz Şehre Leziz Su, pp. 35-37.

22 BOA, İ.MMS 94-3981, p. 1; Nuran Yıldırım, "Su ile Gelen Ölüm: Kolera ve İstanbul Suları", Toplumsal Tarih, 145 (2006), p. 5. 
culture that increased in the second half of the century. The pollution and lack of maintenance of the Istanbul waterways was voiced by many for centuries, and occasionally typhoid epidemics appeared in the capital due to the pollution ${ }^{23}$. Moreover, a majority of the public believed that contaminated water was the cause of the epidemics in Istanbul. Consequently, most of the time the newspapers of that period were full of advertisements promoting medication used for diseases contracted from polluted water ${ }^{24}$. In the 1900 s, the Ottoman public considered the hygiene of Istanbul's waters unsafe to the extent that it was compared with the Ganges River ${ }^{25}$.

Beginning from the second half of the nineteenth century, the water shortage in the capital Istanbul and debates on whether or not the water available was clean occupied a significant place on the daily agenda. Especially during the 1877-78 Russo-Turkish War, the Russian army that reached as far as San Stefano (now Yeşilköy) and destroyed some of the dams made dealing with the issue of water shortage and pollution essential during the reign of Abdulhamid II. There were certain factors that caused pollution of drinking water in the city of Istanbul. While one of these factors was pollution that occurred at the water sources, another was factors that caused the water pollution in the dams and along the canals supplying the water ${ }^{26}$.

In 1880, a commission consisting of the Şehremini (Mayor of Istanbul) Mazhar Pasha and 15 officials selected from various administration departments upon order of the sultan, carried out surveys and put forth suggestions such as raising the dams, making improvements to the waterways, and also proposed various other improvements ${ }^{27}$. A report, possibly by the same commission, stating that the water in Bend-i Kebir, the capital's most important water reservoir, was contaminated led to disputes regarding the relocation of three of Istanbul's villages, revealing the extent to which nature and health, health and politics and the connection

23 Galib Ata, "İstanbul Evkaf Suları", p. 161.

24 Haydar Kazgan, Sami Önal, İstanbul'da Suyun Tarihi, İstanbul 1999, p. 39.

25 Kazgan-Önül, Ibid, p. 156.

26 Compared with cleaning the pollution at the water source, it was relatively easier to control pollution with the cleaning of the reservoirs and maintenance of water canals. As a result, various repairs and sanitization efforts were carried out throughout the $19^{\text {th }}$ century. For detailed information on operations to keep the water canals clean see. Kurt, "Payitaht'in Suyunu Muhafaza Etmek"; Yurdakul, Aziz Şehre Leziz Su, pp. 129-160.

27 Galib Ata, "İstanbul Evkaf Suları", p. 161. 
with all these was integrated with the city texture. Upon receiving news of the polluted waters, in an attempt of preserving the waters, protecting the people from epidemics and preventing a water shortage Abdulhamid II immediately sent a new delegation consisting of individuals from his close circle and names he trusted to the region to inspect, clean and repair the dams ${ }^{28}$.

In the report submitted to the Council of Ministers (Meclis-i Viukela) by the delegation in 1880, it is stated that animal manure collected in the vineyards, orchards and gardens and -because there was no sewage- waste from toilet pits was polluting the waters of Bend-i Kebir, and that the village should be relocated immediately ${ }^{29}$. However, because the municipality considered the report prepared by the delegation inadequately detailed, it was decided that another commission should be formed ${ }^{30}$. The duty of this commission was to investigate what had to be to repaired; clean and protect the dams, and prepare a report determining the $\cos ^{31}$.

In the report presented by the commission led by Riza Bey, Chief of General Staff (Erkan-ı Harbiye) in 1881, the importance of Bend-i Kebir in terms of supplying water to the capital Istanbul was strongly emphasized. According to the commission, although there was no threat of pollution discovered in the Topuzlu, Kirazlı and Ayvad dams, none of these dams could supply the volume of water obtained from Bend-i Kebir. Istanbul's constantly increasing made it necessary to supply a greater volume of water to satisfy the needs of the capital's residents, and due to this Bend-i Kebir was extremely important in terms of supplying Istanbul's water demands. According to the commission, the cause of the pollution of the dams was the population increase that occurred over time in the Belgrad district, which was established after the Belgrad city was seized in 1521. In fact, it appears to have been foreseen that the waters of the dams could be polluted if there was an increase in the village population that originally consisted of 10 houses and 40 people when the village was first established, because imperial orders were issued preventing the expansion of the village ${ }^{32}$. Nevertheless, these orders were

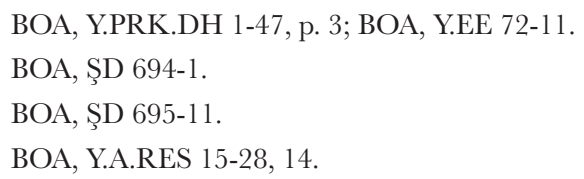

We see that since the early period numerous decrees were issued prohibiting habitation along the waterway routes. For the various rulings issued on the topic from the sixteenth to the eighteenth 
not implemented and eventually the Belgrad village was transformed into a large village that had a population of one thousand residents. As this gradually growing village had no sewage facilities or wells, all the waste from this populated area began to flow into the dam's waters. Additionally, residents of the village would take their animals down to the dam to graze, wash their clothes in the dam's water and were even paid to wash bedding and clothing in the dam brought to the village from hospitals and houses in and around Beyoğlu $\mathrm{u}^{33}$. Moreover, although they were settled there to ensure the dams were kept clean and to carry out repairs, over a period of time the village residents turned five thousand decares of the water basin, where it was totally forbidden to engage in agriculture, cut down trees or even walk, into agricultural fields. This led to mud accumulating on the bottom of the flowing waters in the dam, and when it rained or snowed this caused the mud to be swept in the dam. Similarly, because the spring water sources between Bend-i Kebir and Topuzlu Bend, also called qatma or appendage, were surrounded by fields, the channels collapsed and especially during winter a majority of the water that came from here was wasted.

The commission believed that there were two options to preserve the water channels supplying Istanbul. The first was to spend 60.000 lira at once and relocate the residents of the village to another region and turn the area to its original state of grassland and forests by disposing of the agricultural fields, and rooting up the vineyards and fruit trees. The second option was to open a deep dyke on the Bend-i Kebir side of the Belgrad village so all the waste from the village would be collected and transferred to areas via sewage channels in a way that it would not flow into the dam's waters. However, even if the sewage channels were constructed, if the fountains remained inside and outside the village the villagers would continue their daily activities here such as washing clothing, and this polluted water would continue to flow into the dam waters. So, the commission recommended ensuring

century see. Said Öztürk, İstanbul'un Tarihi Su Yollar: Muhafaza ve Bakrmı, Vol.I, (İstanbul, 2006), 43. As for the Belgrad village, because of its proximity to the source of Bend-i Kebir, in 1858 permission was rejected for the construction of an inn and sherbet house requested to be built as an annex of the church, and an order for its demolition was issued. The grounds of the ban was because the buildings were close to the stream and the danger of this polluting Istanbul's waters. BOA, A.MKT.MVL 98-43.

33 In fact, this was not actually a new implementation. In 1725 residents of the village were issued a warning and fined for washing clothing in the dam's waters and for allowing their animals to graze close to the water. Reşad Ekrem Koçu, Istanbul Ansiklopedisi, Vol. 5, p. 2496; Nirven, İstanbul Sular, pp. 108-109. 
the fountains were only used for drinking water, and enclosing Bend-i Kebir with thick trees and fencing to prevent animals from reaching the waters. In addition, the government would also have to prevent the use of land, ban the sale of land and the construction of buildings here to prevent a population increase in the village. As the commission considered relocating the village a difficult and costly option to enforce, the proposal of constructing sewage canals was put forth ${ }^{34}$.

Commission chairman Rıza Bey, head of the Istanbul city council (Şehremaneti meclisi) Remzi Effendi, Repair Manager of the Treasury of Pious Foundations and Director of Mining and Forestry Bedros Bey came together on many occasions with members of the Council of State's Internal Affairs Department to assess the commission's report, but was only able to reach a decision in December. As a result of negotiations, the sewage project that was almost 4.5 million kurus less expensive than relocating the village was approved. Residents of the village who wanted to rebuild their houses were to be allocated spots that would not pollute the dams, and washing clothing in the village was to be totally banned. New land was not to be opened for use or settlement, and agriculture on land where the owners did not have deeds was to be ceased immediately. Owners that did have deeds were to dig dykes below their land preventing any waste flowing into the dam ${ }^{35}$. In all likelihood, those who made this decision were aware that these preventive measures would not materialize with the existing state mechanisms. But the empire was caught up between the financial crisis it was suffering and the capital's water supply, and was unable to find any other way out of the situation.

Nevertheless, as these negotiations were carrying on, the shortage of water in Istanbul was also continuing. When Abdulhamid II learned that there was very little water left in some of the dams and the others were completely empty, he ordered for another commission to be formed within the Istanbul Municipality department to solve the capital's water issue ${ }^{36}$. The commission traveled to Belgrad and Bahçeköy villages accompanied by a group of engineers assigned to conduct more detailed inspections of the area, and on 8 February 1882 the commission submitted a report to the Vizierate. The commission stated that Bend-i Kebir was 'in a state totally deprived of hygiene' and because the dam's waters were not protected from certain 'disgusting waste', the dam was in a terrible condition.

34 BOA, Y.A.RES 15-28, 6.

35 Ibid, 14.

36 BOA, İ.DH 842-67695. 
According to the surveys, the cause of the pollution was the neighborhoods of the Belgrad village that were divided into two, namely the lower and upper neighborhoods and the location of the Belgrad village within the dam's basin ${ }^{37}$. For as long as the village remained in the area, in the words of the commission 'It is inevitable that all kinds of refuge and waste originating from the village could flow with rain/water into the dam's waters.' Moreover, as residents of the village were unable to make a living by agriculture, timber trading and laundrywashing had become their main source of living. So whatever measures were taken, it would be impossible to prevent residents of the village, who had turned washing the clothing and laundry from surrounding mansions and hotels into a form of trade from continuing this service. Despite the fact that due to the low cost the previous commission suggested the option of constructing sewage canals during their inspections, as a result of detailed inspections carried out by the new commission it was decided that this alternative would not provide the desired results as the village had grown rapidly over 25 years, and because people wanted to build summer houses there it was clear that this rapid growth would continue ${ }^{38}$. Briefly, the commission believed that it was essential for the Belgrad village to be relocated to solve the water issue in Istanbul and particularly in Beyoğlu, and for the water level in the dams to increase ${ }^{39}$.

37 For a map showing these two neighborhoods see. BOA, Y.A.RES 15-28, 2. These two areas officials later called the Belgrad village and Kömürcü village are referring to the lower and upper neighborhoods.

38 One of the main causes of this population growth without doubt is because the village was considered as a summer resort. Although the sayfiye (summer house/countryside) culture existed in the Ottoman Empire from the early period, this did not gain popularity due to the inconvenience of access. With developments in transportation technology, from the second half of the nineteenth century having a summer house in the countryside, in addition to their main homes, became popular among the upper-class families. Life in the countryside was also considered to be beneficial in health terms and was recommended by doctors. The most popular among these summer venues was the coastal areas of the Bosphorus, the Prince Islands and Yeşilköy. Ekrem Işın, "19. Yüzyılda Modernleşme ve Gündelik Hayat”, Tanzimat'tan Cumhuriyet'e Türkiye Ansiklopedisi, Vol. 2, İstanbul 1985, pp. 554-555; Yusuf Ragib, Ístanbul Sayfiyeleri: Tebdil-i Hava, Istanbul 1323. Because of its fresh air and nature, since the seventeenth century the Belgrad village became a sayfiye place where Europeans, embassy officials and European travelers built their summer homes. In the nineteenth century, wealthy Turkish people began to come to the village that became famous especially for its taverns. Reşad Ekrem Koçu, Istanbul Ansiklopedisi, Vol. 5, p. 2476; Eremya Çelebi Kömürciyan, İstanbul Tarihi, İstanbul 1988, pp. 31,199; Maurice M. Cerasi, Osmanl Kenti: Osmanl Imparatorluğu'nda 18. ve 19. Tüzyllarda Kent Uygarlı̆̆ ve Mimarisi, Istanbul 1999, p. 203; BOA, DH.MKT 192-42, 33.

39 In August 1893, possibly to confirm the commission claims of the population increase in the

Belleten, Aralık 2021, Cilt: 85/Sayı: 304; 933-966 
The new commission determined that relocating the village could be completed at a much lower $\operatorname{cost}^{40}$, on average the same cost as constructing dykes which was estimated to be around 12.000 lira. The commission carried out investigations in regions where the village could be located, and decided that the most suitable location was Burunsuz Mandira, an estate 45 minutes away from the Belgrad village, and even reached an agreement with the owners to purchase the land for 1.500 lira $^{41}$. The Assembly of Ministers approved the commission's proposal to move the Belgrad village to the Burunsuz Mandira ${ }^{42}$. This solution would be a firmer step in meeting the water demand of the capital at a relatively lower cost.

This period when the Assembly of Ministers reached this conclusion concerning the Belgrad village, was also a time when important decisions were made regarding the economic situation in the Ottoman Empire. In December 1881, with the Decree of Muharram the Empire's debts were revised with various reductions, and the six taxes called rüsum- $\iota$ sitte and management of the taxes was to be handed over to the OPDA, Ottoman Public Debt Administration that was to be established. With the administration that took office in 1882 and took control of a part of the Ottoman financial sources, a much different process began concerning the management of the Ottoman financial structure ${ }^{43}$. Following the Muharram Decree, Abdulhamid II was extremely cautious when it came to borrowing, and at the same time also struggled systematically with the budget deficit. Due to this, the period between 1881-1890 was a term for making cuts economically; increasing incoming revenue and cutting back on expenditure ${ }^{44}$. So in 1892 when the economy and rotation experienced in the utilization of financial sources raised the question how will

Belgrad village, the government requested via the Istanbul Greek Patriarchate that the priest of the Panayani Church and his trustees sent detailed documentation of the married and single members of his community (the village residents), the houses where they lived and shops they owned. BOA, Y.PRK.AZN 2-5, 1. In all likelihood, with this documentation the government would have confirmed the claims of population increase and also calculated the cost of expropriation in the village.

BOA, Y.A.RES 15-28, 13; BOA, DH.MKT 1460-82; BOA, DH.MKT 1470-19.

41 BOA, Y.A.RES 15-28, 13.

42 Ibid, 22; BOA, Y.A.RES 16-47, 7 and 2.

43 For more detailed information on this process see. Donald C. Blaisdell, European Financial Control in the Ottoman Empire, 1940; Kirkor Kömürcan, Türkiye Imparatorluk Devri Dış Borçlar Tarihçesi, İstanbul 1948, pp.114-47; Nihad S. Sayar, Türkiye İmparatorluk Dönemi Siyasi, Askeri, İdari ve Mali Olaylan, İstanbul 1978), pp. 53-69, 250-57; A. Du Velay, Türkiye Maliye Tarihi, Ankara 1978, pp. 271-438.

44 Ömer Faruk Bölükbaşı, Tezzid-i Varidat ve Tenkih-i Masarifat: II. Abdülhamid Döneminde Mali İdare, İstanbul 2005, pp. 55-77. 
the costs needed for the relocation of Belgrad village be met, the topic suddenly disappeared from the agenda and was suspended for almost five years.

The topic of moving Belgrad village emerged once again in the beginning of 1887 with the decree issued by Abdulhamid II for improvements to be made to the waterways in an attempt of overcoming the water issue in Istanbul. So another commission was formed within the municipality to discuss the water issue in Istanbul, and other matters related to solving this in detail ${ }^{45}$. In the report submitted by the new commission in July, it not only emphasized supplying water to Istanbul, but also the importance of supplying clean water, and similar to the commission's report in 1882, moving the Belgrad village was cited as the only solution for cleaning the Bend-i Kebir's waters. Members of the commission expressed the same opinion as the former commission regarding the village being moved to Burunsuz Mandira ${ }^{46}$ and recommended the land was purchased immediately for 1.700 lira before any new buyers came forward for the land, and before the price was increased ${ }^{47}$. However, despite the reports and the decision of the commission, due to the ongoing financial crisis in the summer of 1891 the money to purchase Burunsuz Mandira had still not been found and because of this discussions were reopened on whether or not purchasing the land was really necessary. The State Council (Şura-yn Devlet) ended these debates with its decree dated 14 July 1891, and emphasizing that the village was to be relocated under any circumstances, it stated that purchasing the land immediately would be more beneficial $^{48}$. In the meantime, complaints began to emerge from residents of the village, as permission to construct new buildings and repair existing buildings in the Belgrad village that had been the topic of dispute for ten years was rejected. Because of this, some of the houses in the village had collapsed and the remaining houses were in ruins, on the verge of collapsing ${ }^{49}$.

The fifth cholera epidemic that broke out in 1892 and spread rapidly all over the world was a turning point in the process of moving of the villages. In 1882, there were cholera epidemics in France, Germany, Belgium, England, Denmark, Austria, Hungary, Russia and Iran. The cholera cases were extremely severe especially in the port cities of Paris, Hamburg, Baku and Russia. The possibility of

Belleten, Aralık 2021, Cilt: 85/Sayı: 304; 933-966

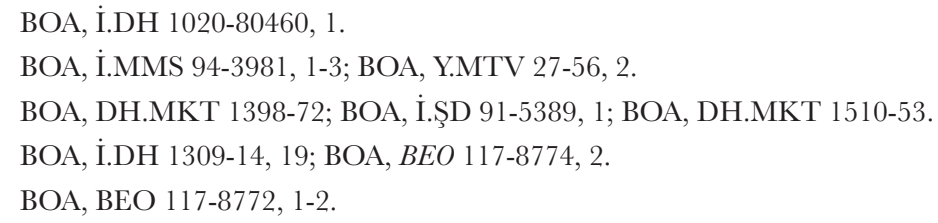


the cholera epidemic spreading to the Ottoman lands was a great concern for the Sultan. In view of this, Chief Inspector of the Istanbul Public Health Department Colonel Bonkowski Bey was asked to carry out inspections in Istanbul ${ }^{50}$.

As a part of these inspections, General Staff Colonel Ali Avni Pasha and the Imperial Chemist (Serkimyager) Bonkowski Pasha were sent to the Belgrad and Kömürcü villages ${ }^{51}$. In the report submitted in September 1892, it was confirmed that most of the houses in this village that consisted totally of Greeks were in ruins, and it was stressed that harmful human and animal waste was flowing into the streams, then into the Bend-i Kebir and the Topuzlu Bend and this was polluting the dam's waters ${ }^{52}$. Similar to previous commissions, this commission proposed two options as a solution for this issue. The first was to construct sewage canals that would be not only be a more expensive method, but also not provide the hygiene required. The second option, that also appeared to be the most feasible, was to relocate the village somewhere else. But contrary to the former commissions, this commission did not consider moving the village to Burunsuz Mandira suitable. First and foremost, the land had a rocky structure and this would not be suitable for the village residents that were already poor. Moreover, Burunsuz Mandira would cause many problems in terms of 'controlling' the residents that were to move here ${ }^{53}$. According to the commission, if the village moved to Burunsuz Mandira, there was a high possibility that the people would turn to tobacco smuggling as their main source of income ${ }^{54}$. In view of this, a proposal was made to the village residents to resettle on the land on the other side of Büyükdere Street opposite Bahçeköy ${ }^{55}$. As this land was not too far away from the Belgrad

50 Yldırım, "Salgın Afetlerinde İstanbul", pp. 141-45. For detailed information on Charles Bonkowski see. Feza Günergun, "19. Yüzyılın İkinci Yarısında Osmanlı Kimyager-Eczacı Bonkowski Paşa (1841-1905)", I. Türk Tıp Tarihi Kongresi, Ankara 1992, pp. 229-52.

51 In some documents Kömürcü is referred to as a neighborhood, in some a village and in others a town. Kömürcü that is clearly connected to the Belgrad village, with its population increase towards the end of the 1880s became a neighborhood, and it is possible to say that since the 1900s it was classified as a village/town. BOA, HR.TH 186-16; BOA, DH.MKT 149-39. There is no doubt that the Belgrad and Kömürcü villages mentioned in the previous commission reports as the lower and upper neighborhoods since the 1890s are the same places.

52 BOA, Y.PRK.MYD 11-93, 2.

53 BOA, Y.PRK.MYD 11-93, 2.

54 Occasionally there were claims that there was tobacco smuggling in the region. For example, in 1874 in a search carried out in the home of a person called Despina an amount of tobacco was seized and other searches in the village revealed that the individual in question hid a large amount of illegal tobacco in a water trough. BOA, HR.TH 14-4.

55 For a plan of the area suggested see. BOA, Y.PRK.MYD 11-93, 1. 
and Kömürcü villages, the people could use the debris from their ruined houses in the construction of their new homes; in this way it would be cheaper, transporting the village would be quicker and the villagers would be willing to move to the new $\operatorname{land}^{56}$.

The report prepared by the commission must have impressed Abdulhamid II because in his decree dated 6 December 1892, he ordered that 'modest and honorable' Muslim immigrants inhabited Burunsuz Mandira rather than the residents of the Belgrad and Kömürcü villages, justifying this stating that Burunsuz Mandira could be used as a center by 'certain unsuitable men' and because of this banditry could begin to appear in the areas surrounding the capital ${ }^{57}$. The sultan compensated the residents of Belgrad for their homes and orchards, and ordered that they should be free to live in a village of their choice or be settled in a suitable village $^{58}$.

At this point, Abdulhamid II's stance towards the residents of the village that entirely consisted of Greeks was interesting. Although he did not state this openly, he realized the strategic importance of Burunsuz Mandira and did not want it to be inhabited by Greeks that could have 'certain unsuitable people' among them. However, the sultan acted compassionate towards the community, virtually like a 'father', and with the consecutive decrees issued, he ordered for the people not to be 'disappointed and to be made comfortable ${ }^{59}$.' One of the reasons was probably the 'father image' Abdulhamid II portrayed to his people, and the other reason was undoubtedly the possibility of great powers such as Russia and England intervening if the Greeks complained. Especially when the city in question was the capital Istanbul, in all likelihood the sultan did not want to take such a risk, and taking various measures he tried to keep the people as comfortable as possible.

56 In addition to public health, the commission also took into consideration that if the proposed village was constructed properly this would also be an example of urbanization for surrounding areas, and because this was on the road leading to the European's entertainment venues it would also leave a good impression on the west. BOA, Y.PRK.MYD 11-93, 2.

57 The Belgrad, Kömürcü and Bahçeköy villages consisted mainly of Greeks. Reşad Ekrem Koçu, İstanbul Ansiklopedisi, Vol. 5, 2476; Reşad Ekrem Koçu, İstanbul Ansiklopedisi, Vol. 4, İstanbul 1960, p. 1795; Osman Nuri Ergin, "Vesait-i Itfaiyyeden İstanbul Suları", 19. ve 20. Küzylda İstanbul Sular, İstanbul 2000, p. 132.

58 BOA, I.HUS 6-49.

59 For a more extensive analysis of Abdulhamid II's paternalist discourse see. Nadir Özbek, Osmanl Imparatorluğu'nda Sosyal Devlet, İstanbul 2011, pp. 32-35, 135-149. 


\section{Putting Theory into Practice: $1893-95$ Cholera Epidemic and Relocation of the Villages}

The 1893 Istanbul cholera epidemic was a turning point in terms of debates concerning the relocation of the Belgrad and Kömürcü villages. Although the issue of moving the villages was not directly connected to cholera ${ }^{60}$, because cholera was a disease that could be spread by water, the importance of the dams that supplied water to Istanbul increased even more during the 1893-95 cholera outbreak. Contamination of the dam's waters could lead to a major disaster where all the residents of the capital and therefore residents of the palace could be infected with the disease. In view of this, from September 1893 the process of moving the villages was taken more seriously, and eventually the relocation of the Belgrad village that had been on the agenda since 1880 began.

In 1817, cholera spread from Bengal to India, and became the most feared disease of the nineteenth century. Cholera first appeared in Istanbul in 1831, then thousands of people died in the 1847-49, 1854-56 and 1870-72 cholera outbreaks ${ }^{61}$. As a result of investigations carried out when suspicious deaths began to occur in Istanbul in 1893, it was confirmed that cholera was the disease causing the deaths ${ }^{62}$. A major part of the precaution measures to be taken was focused on drinking water, as the main cause of the transmission of cholera was water contaminated with excretion from patients infected with the disease. Moreover, the epidemic that broke out in Hamburg in 1892 revealed that public water systems were one of the main causes of the disease spreading ${ }^{63}$. As a result of the studies carried out by Chantemesse, it was determined that the main factors causing the disease were the dysfunctional sewage system and drinking water ${ }^{64}$. Emphasizing that there were only a very few fountains in Istanbul supplying fresh

60 Mesut Ayar - İlhami Yurdakul both associated the moving process of the villages with the cholera epidemic in Istanbul. Mesut Ayar, Osmanl Devletinde Kolera: İstanbul Örneği (1892-1895), İstanbul 2007, pp. 348-352; Yurdakul, Aziz Şehre Leziz Su, p. 131. Although the cholera epidemic speeded up the relocation of the villages, it is also beneficial to point out that the move was a topic of dispute since 1880 .

61 Nuran Yıldırım, "1893 İstanbul Kolera Salgını İstatistikleri”, Tarih ve Toplum, 150 (1996), p. 51; Nuran Yıldırım, "Salgın Afetlerde İstanbul', in Afetlerin Gölgesinde Istanbul: Tarih Boyunca Istanbul ve Çevresini Etkileyen Faktörler", İstanbul, [nd.]), p. 129.

62 Nuran Yıldırım, "İstanbul'da Sağlık Hayatı", Büyük İstanbul Tarihi, Vol. 4, İstanbul 2015, p. 113.

63 Nuran Yıldırım, "Su ile Gelen Ölüm: Kolera ve İstanbul Suları", Toplumsal Tarih, 145 (2006), pp. 2-6.

64 Yıldırım, "Salgın Afetlerinde İstanbul", p. 143.

Belleten, Aralık 2021, Cilt: 85/Sayı: 304; 933-966 
water, Chantemesse stated that due to the limited clean water sources it would be impossible to supply the entire city. Stating that the dam waters were extremely unfit as drinking water ${ }^{65}$ Chantemesse requested that chemical examinations should be carried out on the water ${ }^{66}$.

In accordance with Chantemesse's request, Abdulhamid II appointed another commission to carry out inspections on whether the Taksim and Terkos waters were suitable for drinking or not ${ }^{67}$. Basically, the content of the report submitted by the commission on 17 October 1893 was similar to previous reports. On one side of Bend-i Kebir at the foot of a mountain and 45 minutes distance from Bahçeköy was the Belgrad village, and on the other side the Kömürcü village. Three streams connected to the dam flowed through these villages and as these streams were used by the village residents, they contained various kinds of waste ${ }^{68}$. According to the commission, due to the bacteria found in Bend-i Kebir and the possibility of facilitating the spread of epidemics, the water was totally unsuitable for drinking. In view of this, relocating the Belgrad and Kömürcü villages was essential $^{69}$. Although cholera was not detected in Istanbul waters, the possibility of cholera spreading to Istanbul if there was an outbreak of the disease in the villages deeply concerned the Sultan. Thus in October, the Sultan ordered for the residents of the Belgrad, Kömürcü and Bahçecik (Bahçeköy) to be moved to the villages in Büyükçekmece or Küçükçekmece and for the area surrounding the dams to be evacuated immediately ${ }^{70}$. Thereby, in addition to Belgrad and Kömürcü, this was the first time that Bahçeköy was also cited among the villages that must be relocated. In all likelihood, the reason for this was the location of the Bahçeköy village, as three of the seven dams in total were around Bahçeköy and the other four were close to the Belgrad and Kömürçü villages ${ }^{71}$. Abdulhamid 
II allowed the residents of these three villages he planned to evacuate to move wherever they wished, and requested that on their approval they should be taken to suitable, vacant land. Furthermore, the Sultan also said every effort should be made 'not to offend the people' during the move and to 'ensure they were comfortable ${ }^{72}$.' So, a commission was sent to the villages in question to evaluate the situation ${ }^{73}$.

In parallel with the decision to move the villages, intensive measures were taken to protect Istanbul's waters against pollution (and the cholera disease) until the moving process was complete. In fact, certain precautions were taken to protect Istanbul's waters from the time the decision to move Belgrad village was first given until it was totally evacuated ${ }^{74}$. Nevertheless, the continuation of the problems and the outbreak of cholera that was initially feared in Istanbul led to the issue being taken more seriously. In September 1893, Abdulhamid II issued an order for the locals not to use the dam waters and to supply their water demands from other sources in the $\operatorname{area}^{75}$. Within a few days, Municipality and Gendarme officials inspected the dams and through the mukhtars (heads of the villages) warned the people not to pollute the waters ${ }^{76}$. Immediately after this, precautions such as digging small pits in the houses in the Belgrad village that had no sewage, controlling the water pipes by municipality teams and ensuring the water was kept clean by travelers were enforced ${ }^{77}$.

On the other hand, in October the commission began to conduct property evaluations in the Belgrad and Kömürcü villages. The property and value assessments were carried out by the alderman (ihtiyar heyeti) accompanied by the local nobles. The total value of homes and land in the village proposed for expropriation was determined at $1.410 .625 \mathrm{kurus}^{78}$. At the end of November, the commission visited Bahçecik (Bahçeköy) village, and conducting property

BOA, İ.DH 1309-14, 21.

Abdulhamid II ordered the commission to visit the region the next day. BOA, I.DH 1309-14, 23; BOA, A.MKT.MHM 726-2, 77; BOA, MV 77-40.

BOA, DH.MKT 1598-100; BOA, DH.MKT 1609-86.

BOA, I.HUS 15-166.

BOA, Y.A.HUS 280-39.

BOA, I.HUS 16-43, 1-2.

BOA, A.MKT.MHM 726-12, 8; BOA, I.ŞE 3-22, 7. For the records prepared by the commission containing the value of the property and land to be expropriated in the see. BOA, Y.A.RES 6852. 
evaluations using the same methods they determined the cost of the property and land that was to be expropriated at $1.694 .000 \mathrm{kurus}^{79}$. The reason for higher expropriation value here was because the Bahçecik village was more developed and more valuable. In addition, the commission stated that there appeared to be no reason to move the entire village, and damage caused to the Taksim waters could be prevented by expropriating only a certain part of the village. According to this, it would be possible to keep the dam waters clean by purchasing only eight houses and moving the graveyard beside the church at a cost of 46.500 kuruş $^{80}$.

The discovery of a cholera case in the Bahçecik village they planned to move around fifteen days after the commission report greatly concerned Sultan Abdulhamid II. If the stream that flowed through this village and supplied Istanbul's drinking water was contaminated with the cholera disease, the effects of cholera could spread to a much vaster area. So, the sultan immediately referred the case to the Commission of Public Hygiene and requested that the necessary measures be taken $^{81}$. This cholera case that appeared in Bahçecik put the report prepared a few weeks earlier back on the agenda. So, the decision was made to evacuate the eight homes found to be polluting the dam's waters without delay ${ }^{82}$, and the houses were vacated on 25 December $^{83}$.

The next day, the Council of Ministers decided to move the Belgrad and Kömürcü villages in the early spring ${ }^{84}$. Abdulhamid II issued an order to totally demolish the houses here, and for a department and 'chateau style' patrol station to be constructed-in an area that would cause no harm to the dams-on the site for guards and forestry officials to live. According to the decree issued by Abdulhamid II, all the orchards and plantation fields were to be removed and replaced by woods. The

79 For the land and property register of the Bahçecik village and records of their value see. BOA, Y.PRK.KOM 8-44.

80 However, if the commission decided to reconstruct the dam that had begun and was abandoned on the Şeytan stream, it stated that like the other two villages, Bahçecik would also have to be moved to another location. BOA, I.ŞE 3-22, 13.

81 BOA, I.HUS 19-4; BOA, İ.ŞE 3-6, 2-4; BOA, İ.ŞE 3-13, 2, 5-6.

82 For the time being, the residents of these eight homes were to stay in a suitable place in the village or be settled in surrounding villages. Their future was to be determined according to the decision regarding the Bahçecik village. BOA, I.ŞE 3-11, 1-3.

83 BOA, BEO 330-24710. For the property census and value of the vacated homes see. BOA, A.MKT.MHM 726-3, 69, 71.

84 BOA, İ.ŞE 3-22, p.12. For the list regarding this see. BOA, İ.ŞE 3-22, 10-11; BOA, A.MKT. MHM 726-20, 7. 
sultan also ordered for huts to be constructed in an area suitable for settlement, for the helpless and poor residents living in the village but had no property and living totally dependent on aid $^{85}$. The expropriation and evacuation process of the homes and land in the Belgrad and Kömürcü villages initially planned for spring by the Council of Ministers continued throughout December ${ }^{86}$. In January 1895, earlier than expected, all the property and land in the Belgrad and Kömürcü villages apart from three houses owned by foreigners and the church, was vacated ${ }^{87}$.

There were long debates on where the people evacuated from the villages were to be settled. The poorer residents of the village considered the expropriation value to be low and if they were told to leave after receiving the money a majority would 'stay somewhere as guests', while the others would spend all their money searching for somewhere to live and would be left 'poor and destitute.' Because of this, the poorer people requested settling on one of the empty plots in Maslak or Kanl Kavak and establishing a village there ${ }^{88}$. The governor (mutasarrnf) of Küçükçemece emphasized that moving all the people to one village would be more appropriate and proposed moving them to a plot of land in Uzuncaova, 1.5 $\mathrm{km}$ away from Kemerburgaz. In addition, the governor also believed this should be seriously considered as an option because the residents of Küçükçekmece, the Küçükköy, Terkos and Cebici villages were also Christian and it was close to Istanbul $^{89}$. Eventually, some of the village residents refused being settled together and moved to areas such as Büyükdere and Feriköy. Homes were built for the poorer people who agreed to live within the borders of Küçükçekmece on a vacant plot of land located close to Kemerburgaz ${ }^{90}$.

85 BOA, İ.ŞE 3-22, 15.

86 For detailed information on the evacuation process see. BOA, A.MKT.MHM 726-3, 18; BOA, MV 82-29; BOA, Y.A.HUS 313-86. BOA, A.MKT.MHM 726-3, 10; BOA, Y.MTV 110-17; BOA, Y.MTV 110-66; BOA, BEO 539-40377, 2.

87 BOA, A.MKT.MHM 726-20, 3-4. The demolition decision regarding the church and holy spring (ayazma) was eventually issued in early November 1895 after long correspondence between the Greek Patriarchate and the Sublime Porte. For this process see. BOA, DH.MKT 192-42, 4950; BOA, MV 83-58; BOA, A.MKT.MHM 726-20, 2; BOA, ŞD 2663-31, 1; BOA, ŞD 364-7, 1-4; BOA, A.MKT.MHM 726-3, 8; BOA, DH.MKT 2272-2; BOA, DH.MKT 2459-64; BOA, DH.MKT 559-43.

88 BOA, A.MKT.MHM 726-3, 61; BOA, A.MKT.MHM 726-11, 5.

89 BOA, A.MKT.MHM 726-3, 59.

90 BOA, A.MKT.MHM 726-20, 5-6; BOA, Y.MTV 111-67; BOA, Y.MTV 114-107. For the construction process of the houses see. BOA, ŞD 776-6, 1-2; BOA, DH.MKT 192-42, 39; BOA, I.DH 1321-37, 1-2; BOA, ŞD 777-26; BOA, ŞD 777-30, 1-2; BOA, Y.MTV 121-28; BOA, 
Although the initial panic was over, all the measures taken to prevent the pollution of the dam's waters in the village in question failed due to the rain and snowfall in the winter months ${ }^{91}$, and this raised the question of what to do about the remaining homes in the Bahçecik village. Varying opinions put forth previously by the two separate commissions led to disagreement between the Council of Ministers and the Municipality, and the final decision regarding Bahçecik village was left to Sultan Abdulhamid II. ${ }^{92}$ Pointing out the importance of the hygiene of Istanbul's waters, Abdulhamid ordered that the village be moved immediately ${ }^{93}$. However, the State Treasury, that was already having difficulty even paying the government employee's salaries, did not have a sufficient means to pay for the expropriation of the three villages. In view of this, on 1 August 1894 the Council of Ministers proposed delaying the expropriation until the following year ${ }^{94}$. Taking into consideration the importance of the matter and the interests of the village residents, in October it was decided that the sum in question should be used from borrowed funds put aside by the Ministry of Finance for unexpected expenditure ${ }^{95}$.

DH.MKT 439-77; BOA, İ.ŞE 9-6, 1-5. The process of moving the villages gives us an idea of the limits of the Muslim-non-Muslim integration in the Ottoman cities through the Tanzimat reforms. Before the Tanzimat era, settlements in the city were shaped around neighborhoods determined by religious segregation because in the Ottoman society Muslims and non-Muslims were banned from living in the same neighborhoods. When the ban on Muslims and nonMuslims living together was lifted following the declaration of the Tanzimat, naturally a new era began in Ottoman urbanization. In addition, the issue of relocating the three villages shows that despite the lifting of the ban -at least for a short period- the reflexes of the Empire and the people did not change. Indeed, the residents of the villages mentioned above whose populations consisted mainly of Greeks were granted permission by the Sultan to settle in Burunsuz Mandira that was far from the city's settlement areas. At this point, the conduct of the village residents is as striking as that of the state. On their own accord, a majority of the village residents moved to areas such as Büyükdere and Feriköy that had a mainly non-Muslim population. The others were moved by the state to a vacant plot of land close to Kemerburgaz also populated mainly by nonMuslims. This signifies that even after the settlement ban preventing Muslims and non-Muslims living together, was abolished following the declaration of the Tanzimat -at least in this exampleboth Muslims and non-Muslims chose to separate their settlement areas.

BOA, A.MKT.MHM 726-3, 54.

BOA, İ.HUS 21-55; BOA, A.MKT.MHM 726-3, 45; BOA, A.MKT.MHM 726-3, 45-47, 57; BOA, MV 79-96; BOA, MV 79-45; BOA, MV 79-96.

BOA, I.HUS 23-74; BOA, ML.EEM 197-76, 1. Imperial Chemist (Serkimyager) Bonkowski Pasha also carried out inspections in the Belgrad and Bahçeköy villages at the beginning of June and emphasized that the people were desolate because of the uncertainty and stressed that the moving process should be completed as soon as possible. BOA, BEO 422-31588, 2; BOA, I.ML 10-80, 1-2; BOA, MV 80-86; BOA, A.MKT.MHM 726-3, p.29; BOA, Y.A.HUS 301-52. 
Although the Belgrad and Kömürcü villages and eight homes in Bahçeköy had been totally demolished during this period and two years had passed, in summer 1896 no steps had been taken to evacuate the other properties and land in Bahçeköy ${ }^{96}$. In 1896 the issue was raised once again when residents of the village applied to the local authorities to repair their homes that were on the verge of collapse. Emphasizing the necessity of moving this village because of the safety of the dam's waters and the discomfort of the village residents, the Municipality stated that a decision should be made immediately regarding Bahçeköy ${ }^{97}$. Furthermore, there was still not sufficient means in the Finance Treasury and budget to pay the sum of 1.5 million kuruş needed to evacuate the entire village ${ }^{98}$. The Council of State decided to include the cost of moving the village in the following year's budget as this was a direct threat to public health, and until then gave permission for repairs to be carried out on homes in the village ${ }^{99}$.

Despite all the requests to conclude the process and the expropriation costs for the village being included in the 1897 budget, in summer 1900 there was still no steps taken to move the village ${ }^{100}$. In 1905, although there was talk of moving the village in the future and due to this whether or not to give permission for various repairs, it was clear that-at least in short term-moving the village was not on the agenda. Furthermore, it is clear from the correspondence between the ministries that some of the buildings in this village were turned into stables by the military for the animals belonging to the cavalry, and a military based was even constructed close to the village. As a result of negotiations, as it was a basic need even permission was granted to repair the village bakery ${ }^{101}$.

In brief, in 1895 the Belgrad and Kömürcü villages were totally evacuated. Although the decision was given in the commission report to move all the houses

\footnotetext{
consideration of not making the people whose homes were on the verge of collapse from years of neglect, suffer hardship during the approaching winter months. BOA, A.MKT.MHM 726-3, 91.

96 BOA, ML.EEM 382-42, 1.

97 BOA, ŞD 789-15, 8. On many occasions the village residents requested permission to carry out repairs and construction on their homes on the grounds that their homes were in the state of ruins BOA, ŞD 789-15, 9-11. The municipality repeated this request in the following months. BOA, ŞD 789-15, 14-15.

98 BOA, ŞD 789-15, 12.

99 BOA, A.MKT.MHM 726-3, 93; BOA, ŞD 789-15, 2.

100 BOA, DH.MKT 2382-74; BOA, A.MKT.MHM 726-37, 7.

101 BOA, DH.MKT 954-26, 1-2.
} 
in Bahçeköy, only eight homes were evacuated, but when the initial fear passed and due to economy policies being reintroduced, plans to move the village entirely due to the threat of the cholera epidemic never materialized.

\section{Conclusion}

As in the case of the economic perception, consumer patterns, social structure and practices of daily life, the Industrial Revolution also transformed peoples living spaces. One of the direct effects of industrialization on social life was the population gathering in certain cities with the acceleration of migration, and therefore causing the expansion of the physical borders of cities. This expansion towards parts of the cities that were previously unoccupied and different areas becoming settlement areas also caused various other problems. As the cities expanded, another problem that arose was the option of settlement areas and the issue of supplying clean drinking water to the city that emerged due to infrastructure problems. In this regard, the evacuation process of Belgrade, Bahçeköy and Kömürcü villages is an important example of how environmental and ecological factors are important in determining urban plans and residential areas.

The story of these three villages, also gives us an idea regarding the environmental disasters that may result from unguided urbanization and the population growth in the 19th century and the capacity of the Ottoman state to combat this. While the paper reveals that the increase in the sayfiye culture in the second half of the nineteenth century led to the 'discovery' of new settlement areas on one hand, on the other it reveals how this had a negative effect on urbanization and the infrastructural needs of the city. When this is combined with the effects of the Russo-Turkish War (1877-1878), the three villages in question becoming sayfiye places and the increasing population became an issue that could lead to almost all the population of Istanbul being without water, and even worse, the people of the capital, maybe even the palace and military suffering heavy losses of life because of cholera.

The case of Belgrade, Bahçeköy and Kömürcü villages, is also important in terms of showing that the ideal of meeting and protecting the needs of the capital Istanbul, which has been regarded as vital from the early period -even formed the basis of the economic policies- and which represents the reputations of the state and which hosts the most crowded population of the palace, army and empire, continued in the 19th century. Although there was a long delay due to financial 
reasons, it would not be wrong to claim that behind the sensitivity displayed by Abdulhamid II regarding the relocation of the villages -even though this was an extremely costly project- was his consideration for 'protecting the capital.' Therefore, the idea of an epidemic in the capital and the destruction this would cause was one of the most important incentives -even though the solution process was spread over a long span of time- in solving such a costly and complex issue.

\section{BIBLIOGRAPHY}

\section{Archival Sources}

\section{Prime Minister Ottoman Archives (BOA)}

Babıali Evrak Odası (BEO)

Dahiliye Nezareti Mektubi Kalemi (DH.MKT)

Hariciye Nezâreti Tahrirat (HR.TH)

İrade Dahiliye (İ.DH)

İrade Evkaf (İ.EV)

İrade Husisi (İ.HUS)

İrade Maliye (İ.ML)

İade Meclis-i Mahsus (İ.MMS)

İrade Şehremaneti (İ.ŞE)

İade Şura-yı Devlet (İ.ŞD)

Maliye Evrak-1 Emiriye Müdüriyeti (ML.EEM)

Meclis-i Vükelâ Mazbatalar (MV)

Sadâret Mektubi Kalemi Meclis-i Vâlâ Evrakı (A.MKT.MVL)

Şura-yı Devlet (ŞD)

Yıldız Mütenevvi Maruzat Evrakı (Y.MTV)

Yıldız Perakende Adliye ve Mezahib Nezareti Maruzatı (Y.PRK.AZN)

Yıldız Perakende Askeri Maruzatı (Y.PRK.ASK)

Yıldız Perakende Dahiliye Nezareti Maruzatı (Y.PRK.DH) 
Yıldız Perakende Komisyonlar Maruzatı (Y.PRK.KOM)

Yıldız Perakende Yaveran ve Maiyyet-i Seniyye Erkân-1 Harbiye Dairesi (Y.PRK. MYD)

Yıldız Sadâret Hususi Maruzat Evrakı (Y.A.HUS)

Yıldız Sadâret Resmî Maruzat Evrakı (Y.A.RES)

\section{Publications}

Ayar, Mesut, Osmanl Devleti’nde Kolera: Istanbul Örneği (1892-1895), Kitabevi, Istanbul 2007.

Bilgin, Arif, Osmanl Saray Mutfağı (1453-1650), Kitabevi, İstanbul 2004.

Blaisdell, Donald C., European Financial Control in the Ottoman Empire, Columbia University Press, New York 1929.

Bölükbaşı, Ömer Faruk, Tezyid-i Varidat ve Tenkih-i Masarifat: II. Abdülhamid Döneminde Mali İdare, Osmanlı Bankası Arşiv ve Araştırma Merkezi, İstanbul 2005.

Camgöz, Mevlüt, Ekmek, Buğday ve Şehir: 19. Yüzynl Osmanh İstanbul'unda İaşe Meselesi, Kitabevi, İstanbul 2017.

Çeçen, Kazım, Istanbul'da Osmanlı Devrindeki Su Tesisleri, İstanbul Teknik Üniversitesi, Ístanbul 1984.

Çeçen, Kazım, İstanbul'un Osmanl Dönemi Suyolları, İstanbul Su ve Kanalizasyon İdaresi, İstanbul 1999.

Çeçen, Kazım, "Sinan'ın Yaptırdığı Su Tesisleri', Mimarbaşı Koca Sinan, Yaşadı̆̆ı Çăğ ve Eserleri”, Vol. 1, Vakıflar Genel Müdürlüğü, Ankara 1988.

Çelik, Zeynep, 19. Küzyılda Osmanl Başkenti: Değişen Istanbul, Türkiye İş Bankası Kültür Yayınları, İstanbul 2019.

Cerasi, Maurice M., Osmanl Kenti: Osmanl İmparatorluğu’nda 18. ve 19. Yüzyllarda Kent Uygarlı̆̆ ve Mimarisi, Yapı Kredi Yayınları, İstanbul 1999.

Ergin, Osman Nuri, "Vesait-i İtfaiyyeden İstanbul Suları", in İsmail Kara, İlhami Yurdakul (ed.), 19. ve 20. Yüzynlda İstanbul Sular, Vol. 1, İstanbul Büyükşehir Belediyesi, İstanbul 2000.

Faroqhi, Suraiya, Towns and Townsmen of Ottoman Anatolia: Trade, Crafts and Food Production in an Urban Setting: 1520-1650, Cambridge University, Cambridge 1984. 
Günergun, Feza, "19. Yüzyılın İkinci Yarısında Osmanlı Kimyager-Eczacı Bonkowski Paşa (1841-1905)", I. Türk Tip Tarihi Kongresi, Türk Tarih Kurumu, Ankara 1992, pp.229-52.

Güran, Tevfik, "İstanbul'un İaşesinde Devletin Rolü”, İstanbul Üniversitesi İktisat Fakültesi Mecmuası, XLIV (1986), pp. 245-75.

Işın, Ekrem, "19. Yüzyılda Modernleşme ve Gündelik Hayat", Tanzimatttan Cumhuriyet'e Türkiye Ansiklopedisi, Vol. 2, İletişim Yayınları, İstanbul 1985.

İnal, Onur, "Environmental History as an Emerging Field in Ottoman Studies: An Historiographical Overview", The Fournal of Ottoman Studies, 38 (2011), pp. 1-26.

İnalcık, Halil, "İstanbul: Bir İslam Şehri”, İslam Tetkikleri Dergisi, 9 (1995), pp. 243268.

Karpat, Kemal H., Osmanl Nüfusu (1830-1914), Tarih Vakfi Yurt Yayınları, İstanbul 2003.

Kazgan, Haydar - Sami Önal, İstanbul'da Suyun Tarihi, İletişim Yayınları, İstanbul 1999.

Koçu, Reşad Ekrem Koçu, İstanbul Ansiklopedisi, Vol. 4, İstanbul Ansiklopedisi ve Neşriyat, İstanbul 1960.

Koçu, Reşad Ekrem, İstanbul Ansiklopedisi, Vol. 5, İstanbul Ansiklopedisi ve Neşriyat, İstanbul 1961.

Kömürcan, Kirkor, Türkiye Imparatorluk Devri Dış Borçlar Tarihçesi, Milli Eğitim Bakanlı̆̆ı, Ankara 1948.

Kömürciyan, Eremya Çelebi, İstanbul Tarihi, Eren Yayıncllı, İstanbul 1988.

Kurt, Burcu, "Payitaht'in Suyunu Muhafaza Etmek: 1894 Depremi Sonrası Kırkçeşme Su Yolunun Tamiri”, Kanuni Sultan Süleyman Dönemi ve Bursa, Osmangazi Belediyesi Yayınları, Bursa 2019.

Ljungkvist, John - Barthel, Stephan - Finnveden, Göran - Sörlin, Sverker, "The Urban Anthropocene: Lessons for Sustainability from the Environmental History of Constantionople", in Paul J.J. Sinclair, Gullög Nordquist, Frands Herschend, Christian Isendahl (ed.), The Urban Mind: Cultural and Environmental Dynamics, African and Comparative Archaeology department of Archaeology and Ancient History Uppsala University, Uppsala 2010. 
Nirven, Saadi Nazım, İstanbul Suları, Halk Basımevi, İstanbul 1946.

Oğuz, Burhan, Bizans'tan Günümüze İstanbul Sular, Simurg, İstanbul 1998.

Özbek, Nadir, Osmanh İmparatorluğu'nda Sosyal Devlet, İletişim Yayınları, İstanbul 2011.

Öztürk, Said, İstanbul'un Tarihi Su Yollarn: Muhafaza ve Bakrmı, Vol. I, İstanbul Büyükşehir Belediyesi İstanbul Su ve Kanalizasyon İdaresi, İstanbul 2006.

Öztürk, Said, (ed.), Suyu Arayan Istanbul: Vakıf Sular ve Kirkçesme, İstanbul Su ve Kanalizasyon İdaresi, İstanbul 2006.

Sayar, Nihad S., Türkiye Imparatorluk Dönemi Siyasi, Askeri, İdari ve Mali Olaylarn, İİ.T.I.A. Nihad Sayar Yayın ve Yardım Vakfi, İstanbul 1978.

Şahin, Salih (ed.), Istanbul Su Yollarr ve Su Yapılarmın Tarihçesi, İstanbul: İSKI İstanbul $\mathrm{Su}$ ve Kanalizasyon İdaresi, [no date].

Tabakoğlu, Ahmet; Çelik, Gülfettin, Suyu Arayan İstanbul: Vakıf Sulan ve Kirkçeşme, İstanbul: İstanbul Su ve Kanalizasyon İdaresi, 2006.

Velay, A. Du, Türkiye Maliye Tarihi, Ankara: Maliye Bakanlı̆̆ı, 1978.

Yıldırım, Nuran, "Su ile Gelen Ölüm: Kolera ve İstanbul Suları", Toplumsal Tarih, 145 (2006).

Yıldırım, Nuran, “1893 İstanbul Kolera Salgını İstatistikleri”, Tarih ve Toplum, 150 (1996).

Yıldırım, Nuran, “1893’te İstanbul'da Kolera Salgını”, Tarih ve Toplum, 129 (1994).

Yıldırım, Nuran, "İstanbul'da Sağlık Hayatı", Büyük İstanbul Tarihi, Vol. 4, İstanbul Büyükşehir Belediyesi, İstanbul 2015.

Yıldırım, Nuran, "Salgın Afetlerde İstanbul", in Afetlerin Gölgesinde İstanbul: Tarih Boyunca İstanbul ve Çevresini Etkileyen Faktörler, İstanbul Büyükşehir Belediyesi, İstanbul [nd.].

Yıldırım, Nuran, "Su ile Gelen Ölüm: Kolera ve İstanbul Suları", Toplumsal Tarih, 145 (2006).

Yurdakul, İhami, Aziz Şehre Leziz Su, Kitabevi, İstanbul 2010.

Yusuf Ragib, Istanbul Sayfiyeleri: Tebdil-i Hava, İstanbul 1323. 


\section{APPENDIGES}

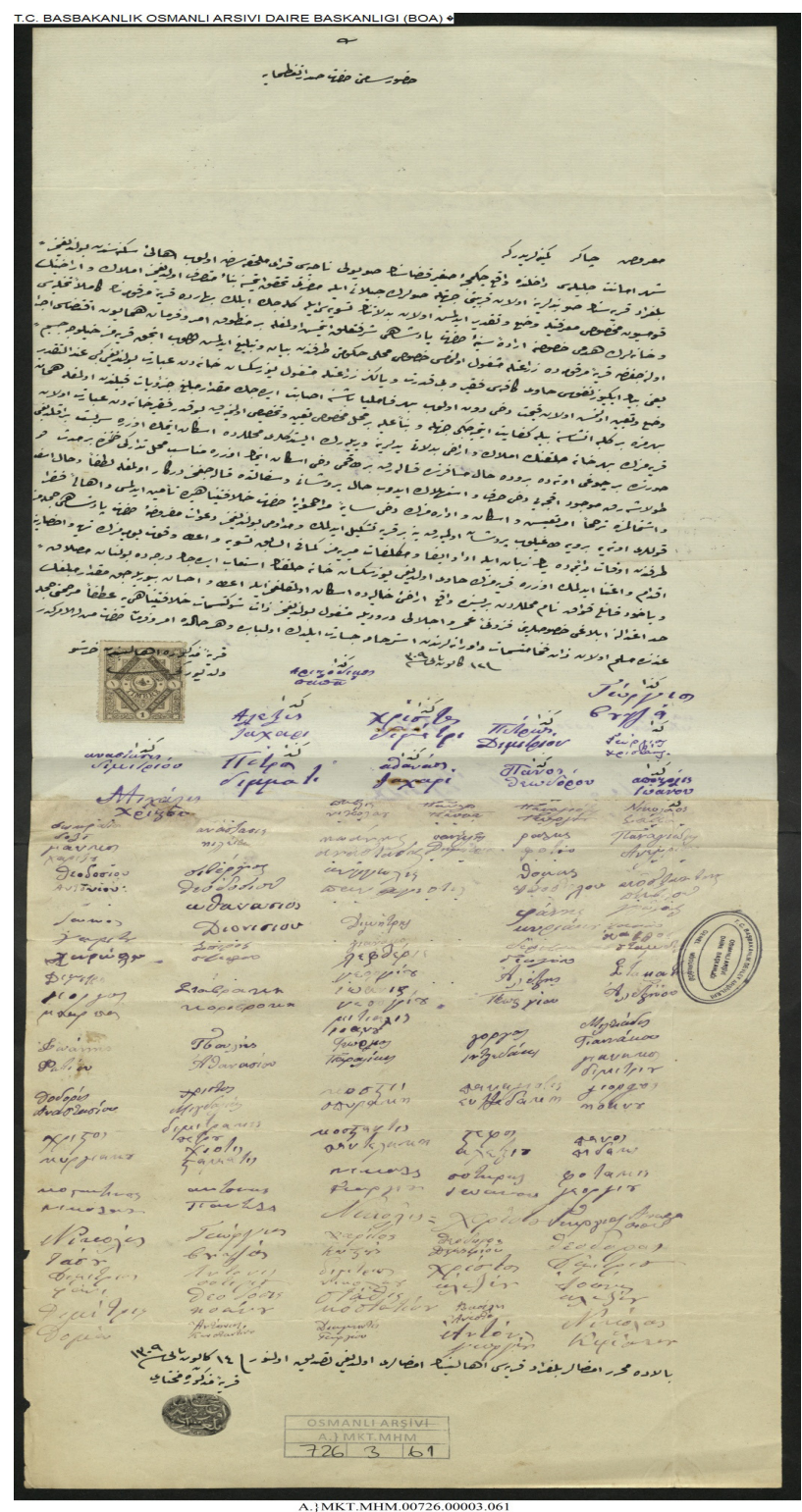

Appendix I: Petition of the people of Belgrade village (BOA, A.MKT.MHM 726-3, 61) 


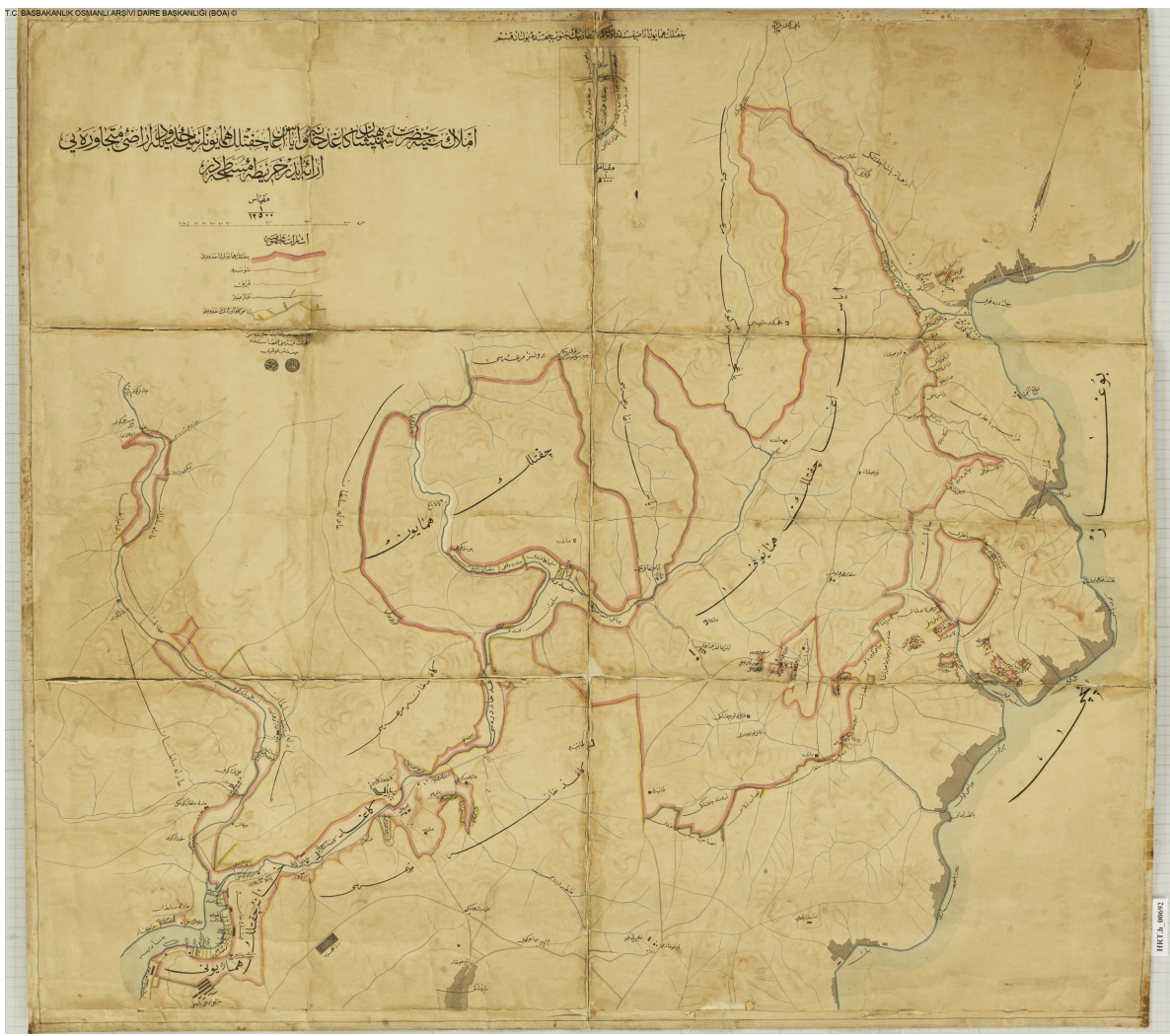

Appendix II: Map Showing the Location of the Villages and the Potential Relocation Points (BOA, HRT.h 692) 


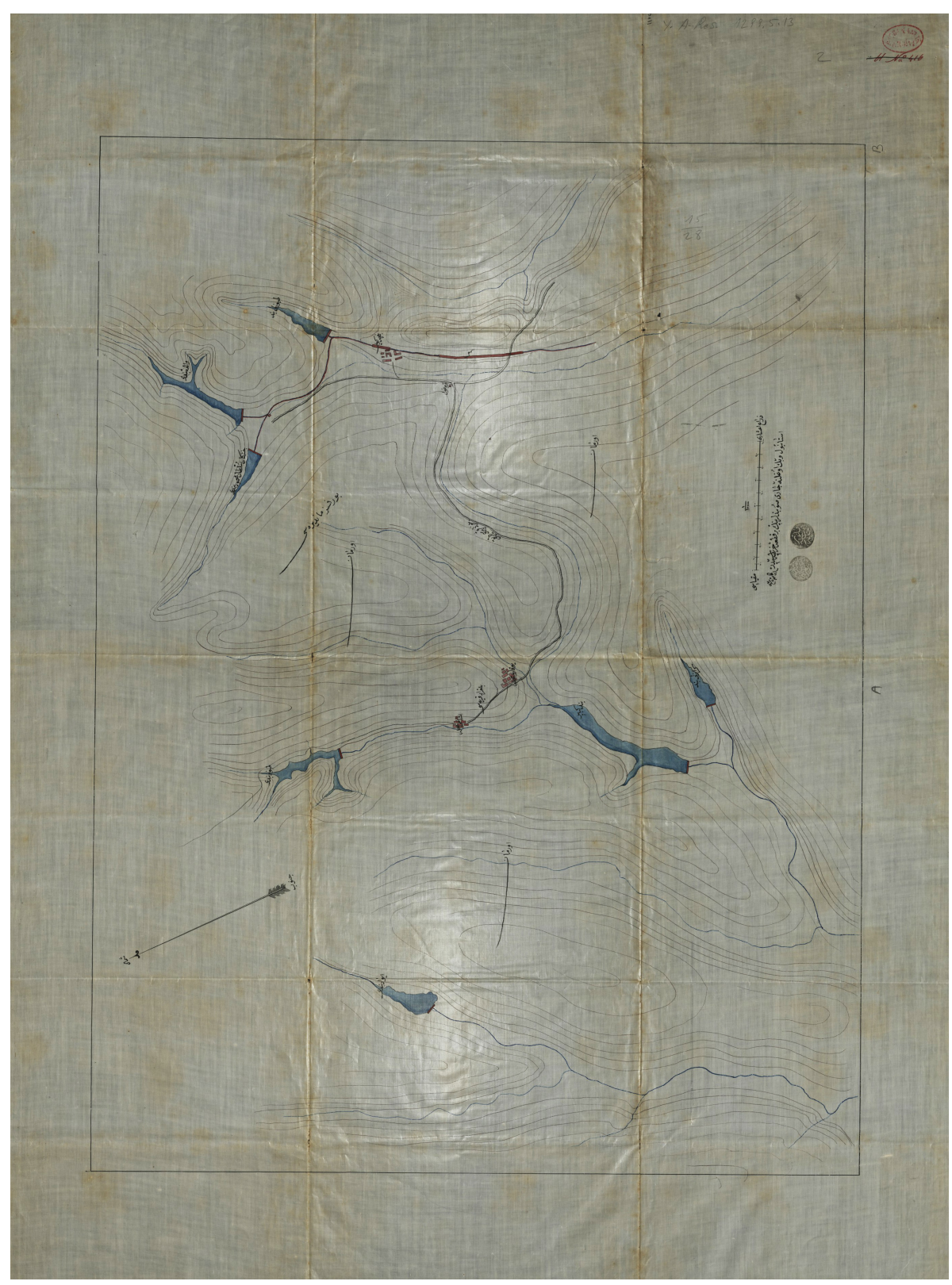

Appendix III: Map Showing the Location of the Dams and the Villages (BOA, Y.A.RES 15-28, 2) 


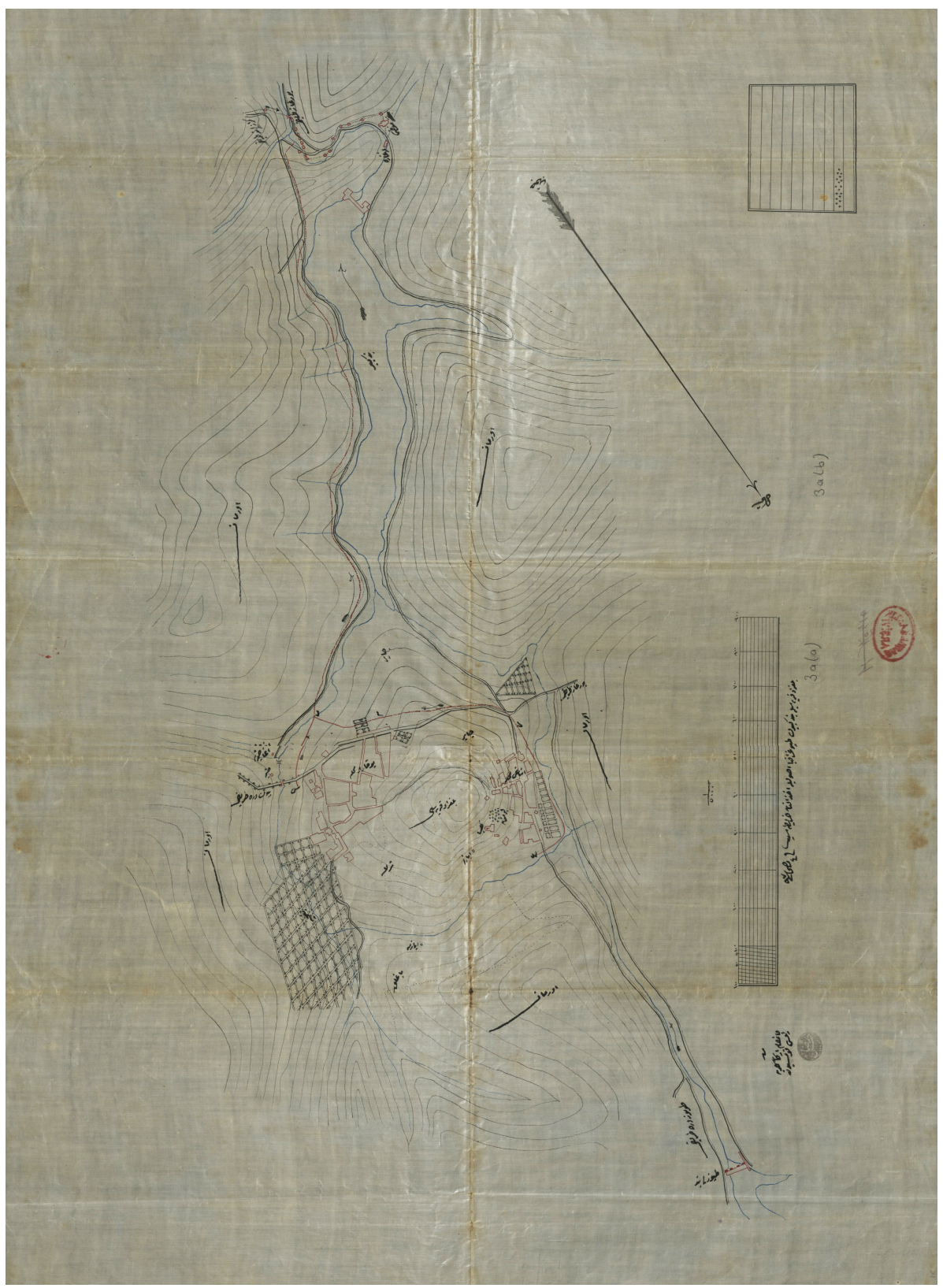

Appendix IV: A Detailed Map of Belgrade Village (BOA, Y.A.RES 15-28, 3)

Belleten, Aralık 2021, Cilt: 85/Sayı: 304; 933-966 


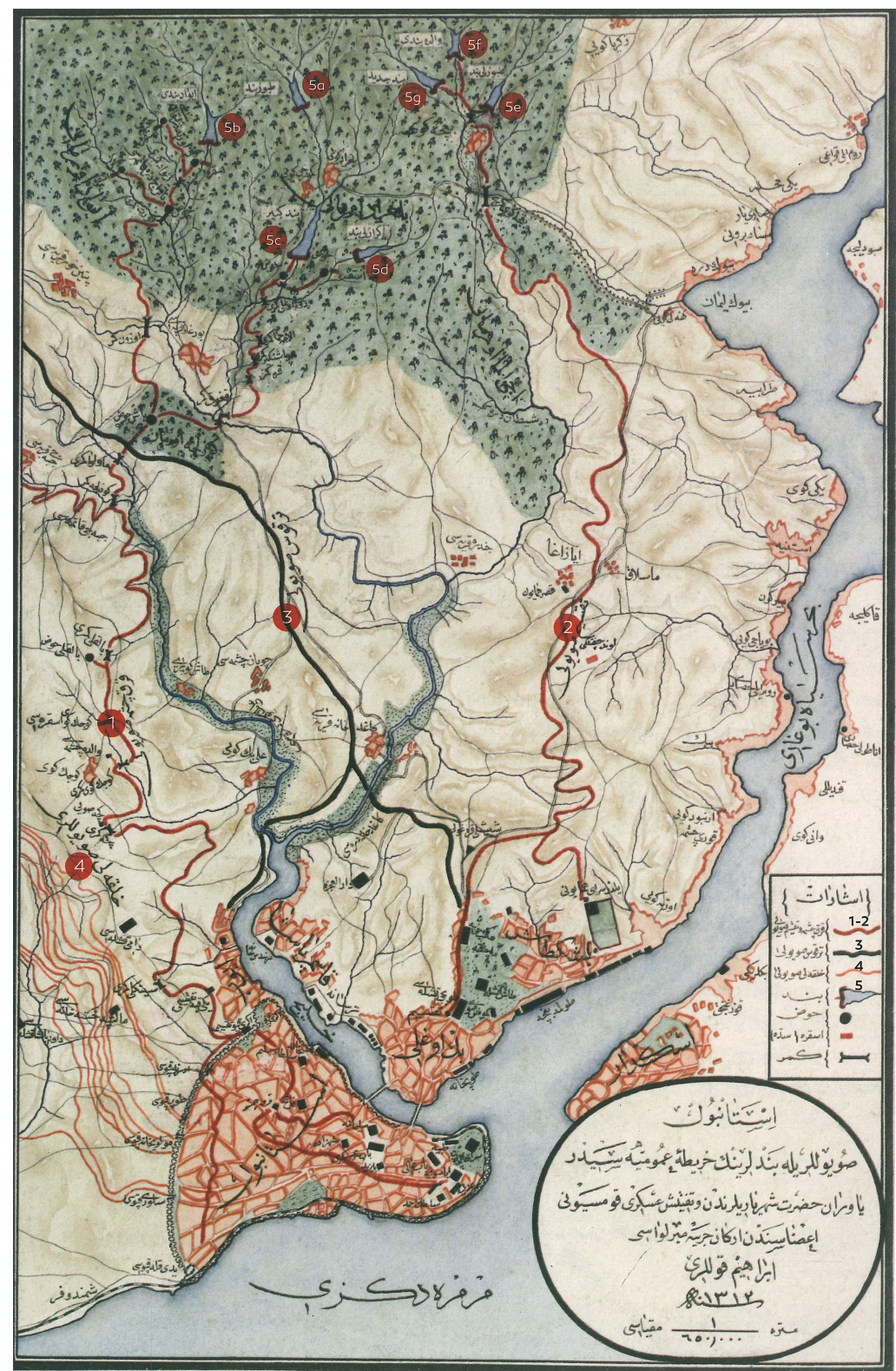

Appendix V: Map showing the city center of Istanbul and the waterways that supply drinking water to the center. (Salih Şahin (ed), İstanbul Su Yollan ve Su Yapılarnnn Tarihçesi, İstanbul: İSKI İstanbul Su ve Kanalizasyon İdaresi, [no date], 22.) 


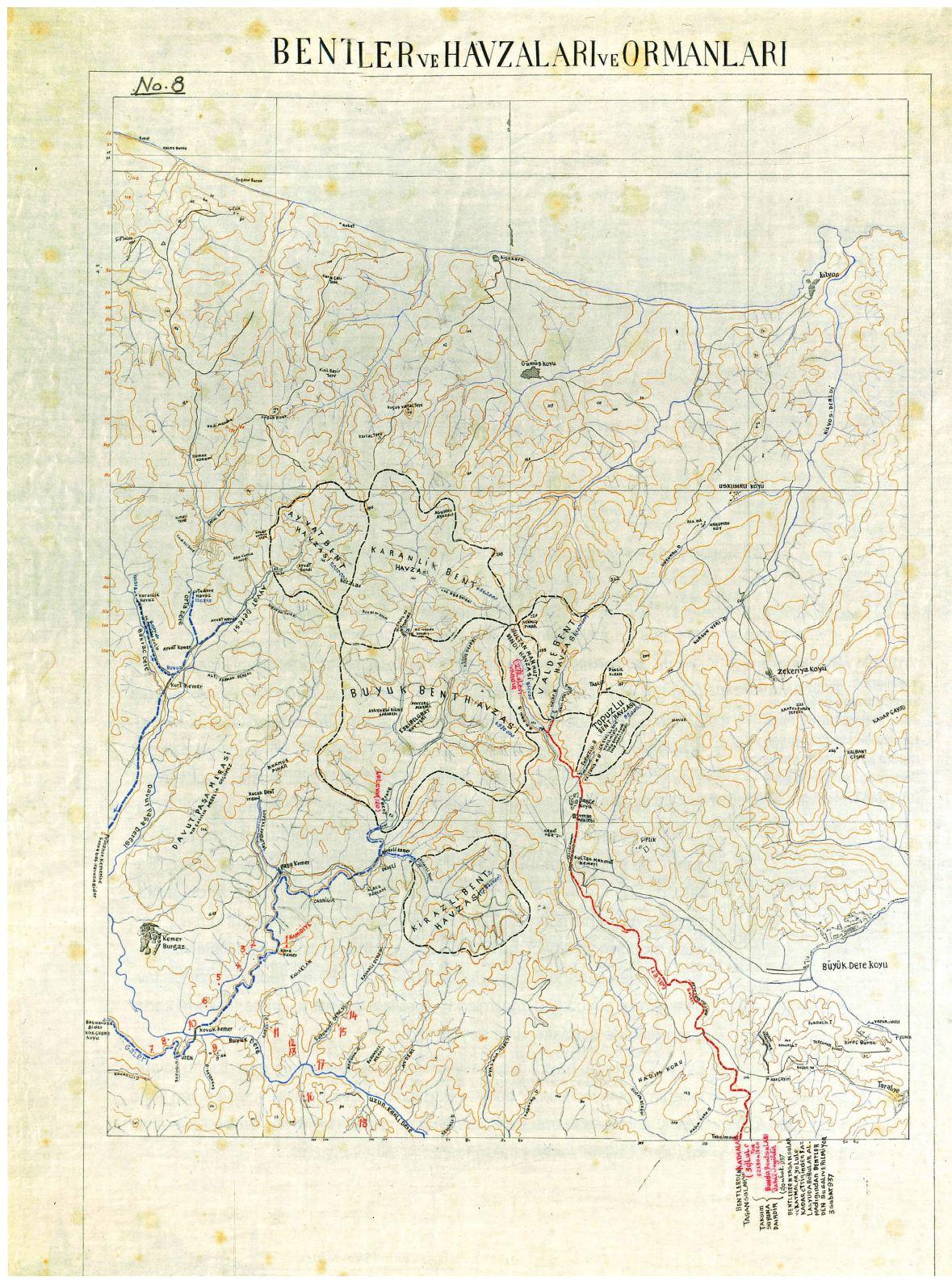

Appendix VI: Map showing the Dams and surrounding residential areas. (Said Öztürk (ed.), Suyu Arayan İstanbul: Vakıf Sular ve Kirkçeşme, İstanbul: İstanbul Su ve Kanalizasyon İdaresi, 2006, 92.) 